\title{
Modernizacja elektrycznych zespołów trakcyjnych serii EN57, EN71 i EW60. Stan obecny i zamierzenia.
}

\begin{abstract}
$W$ artykule opisano zmodernizowane elektryczne zespoty trakcyjne EN57, EN71 i EW60 eksploatowane w kraju, a wyprodukowane wcześniej przez Fabryke Wagonów „Pafawag” Wrockaw w latach $1962 \div 1990$. Przedstawiono $w$ nim zakres modernizacji e.z.t EN57-SPOT, EN57KM i EN57SKM (dla PKP Przewozy Regionalne, Kolei Mazowieckich i Szybkiej Kolei Miejskicj w Trójmieście) oraz EN71 i EW60 (dla Kolei Mazowieckich) zrealizowanych przez Zakłady Naprawcze Taboru Kolejowego „Mińsk Mazowiecki” przy udziale Instytutu Pojazdów Szynowych „Tabor” uczestniczacym $w$ pracach projektowych, badawczych $i$ w procesie dopuszczenia do ruchu po torach PKP PLK S.A. wszystkich zmodernizowanych zespotów. Zaprezentowano również opisy ważniejszych zmodernizowanych układów i systemów oraz zamierzenia przyszłościowe odnośnie ich dalszej modernizacji.
\end{abstract}

\section{Wstęp}

Elektryczne zespoły trakcyjne serii EN57, EN71 i EW60 były zaprojektowane przez Centralne Biuro Konstrukcyjne Przemysłu Taboru Kolejowego (późniejszy Ośrodek Badawczo-Rozwojowy Pojazdów Szynowych) w Poznaniu i produkowane przez Fabrykę Wagonów „Pafawag” Wrocław. Przeznaczone są one do obsługi ruchu aglomeracyjnego i podmiejskiego, ale często wykorzystywane są również dla realizacji przewozów w ruchu regionalnym i międzyregionalnym. Ogółem w „Pafawagu” Wrocław wyprodukowano około 1500 sztuk elektrycznych zespołów trakcyjnych, z których część została wyeksportowana do Jugosławii.

Zestawienie ogólne wyprodukowanych zespołów przedstawiono $\mathrm{w}$ tablicy 1 , a widoki zespołów przed modernizacją na rys. $1 \div 3$. Obecnie zespoły eksploatowane są w większości przez PKP Przewozy Regionalne, Szybką Kolej Miejską oraz przez Spółkę Koleje Mazowieckie.

Zdecydowana większość eksploatowanych zespołów jest w złym stanie technicznym, mimo że przez czterdzieści lat były one $\mathrm{w}$ większym lub mniejszym zakresie modernizowane i modyfikowane, a wyprodukowany tylko w jednej sztuce ponad dziesięć lat temu ED73 cechował się już nowoczesnymi krajowymi rozwiązaniami $[3,4]$.
Dopiero od kilku lat, kiedy część kosztów modernizacyjnych zaczęła pokrywać Unia Europejska rozpoczęto $\mathrm{w}$ Polsce wdrażać program modernizacji zespołów serii EN57, EN71 oraz odnawiać niewykorzystane przez SKM zespoły EW60.

Program ten jest realizowany przez największe polskie zakłady taboru kolejowego takie jak „Pesa” Bydgoszcz, „Newag” Nowy Sącz i Zakłady Naprawcze Taboru Kolejowego „Mińsk Mazowiecki”.

Głównymi celami modernizacji było:

- podniesienie komfortu podróżowania oraz komfortu obsługi (maszynistów, serwisu)

- podniesienie parametrów techniczno-eksploatacyjnych (zmniejszenie awaryjności, podniesienie stopnia gotowości technicznej, ułatwienie obsługi)

- spełnienie norm i przepisów obowiązujących obecnie w ruchu pasażerskim (dotyczy w szczególności komfortu, palności materiałów, wyposażenia itd.)

- przedłużenie czasu eksploatacji zespołów

- optymalizacja kosztów obsługi i napraw.

Dla modernizowanych zespołów przyjęto, że optymalnym okresem do przeprowadzenia modernizacji jest zwykle połowa planowanego całkowitego okresu „życia” taboru.

Ogólne zestawienie elektrycznych zespolów trakcyjnych

Tablica 1

\begin{tabular}{|c|c|c|c|c|c|c|c|}
\hline L.p. & $\begin{array}{c}\text { Seria } \\
\text { zespołu }\end{array}$ & Układ osi & $\begin{array}{l}\text { Moc max. } \\
{[\mathrm{kW}]}\end{array}$ & $\begin{array}{c}\text { Prędkość } \\
\text { max. } \\
{[\mathbf{k m} / \mathbf{h}]}\end{array}$ & $\begin{array}{c}\text { Liczba } \\
\text { miejsc } \\
\text { siedzących } \\
\end{array}$ & $\begin{array}{c}\text { Liczba } \\
\text { wyprodukowanych } \\
\text { zespołów } \\
\end{array}$ & $\begin{array}{c}\text { Lata produk- } \\
\text { cji }\end{array}$ \\
\hline 1. & EN57 & $22+B_{0} B_{0}+22$ & 580 & 110 & 212 & 1412 & $1962 \div 1994$ \\
\hline 2. & EW58 & $\mathrm{B}_{0} \mathrm{~B}_{0}+22+\mathrm{B}_{0} \mathrm{~B}_{0}$ & 1640 & 120 & 212 & 28 & $1974 \div 1980$ \\
\hline 3. & EW60 & $22+B_{0} B_{0}+22$ & 824 & 100 & 164 & 2 & 1990 \\
\hline 4. & EN71 & $22+\mathrm{B}_{\mathrm{o}} \mathrm{B}_{\mathrm{o}}+\mathrm{B}_{\mathrm{o}} \mathrm{B}_{\mathrm{o}}+22$ & 1160 & 110 & $264 / 288$ & $\begin{array}{c}20 \\
\text { (przebudowa 30) }\end{array}$ & $\begin{array}{c}1976 \\
1976 \div 2003\end{array}$ \\
\hline 5. & ED72 & $22+\mathrm{B}_{0} \mathrm{~B}_{0}+\mathrm{B}_{0} \mathrm{~B}_{\mathrm{o}}+22$ & $1160 / 1400$ & 110 & $235 / 232$ & 21 & $1993 \div 1996$ \\
\hline 6. & ED73 & $22+\mathrm{B}_{0} \mathrm{~B}_{\mathrm{o}}+\mathrm{B}_{\mathrm{o}} \mathrm{B}_{\mathrm{o}}+22$ & 1400 & 120 & 235 & 1 & 1997 \\
\hline
\end{tabular}




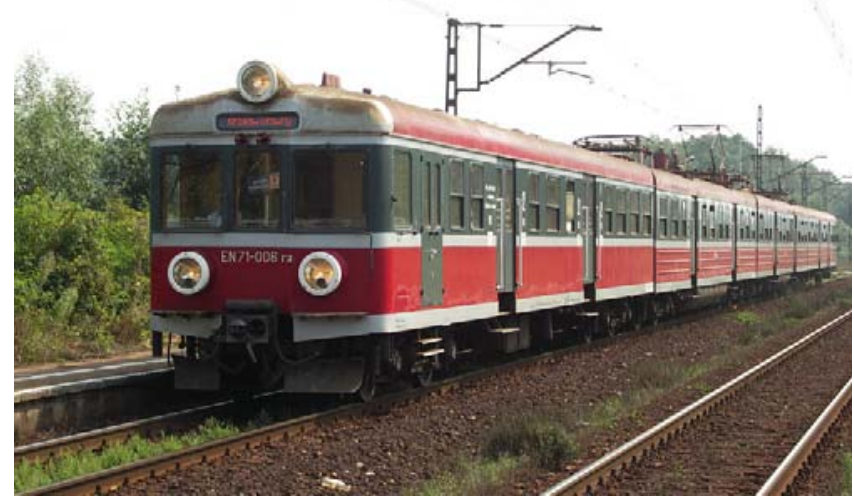

Rys.1. Elektryczny trójczłonowy zespół trakcyjny serii EN57

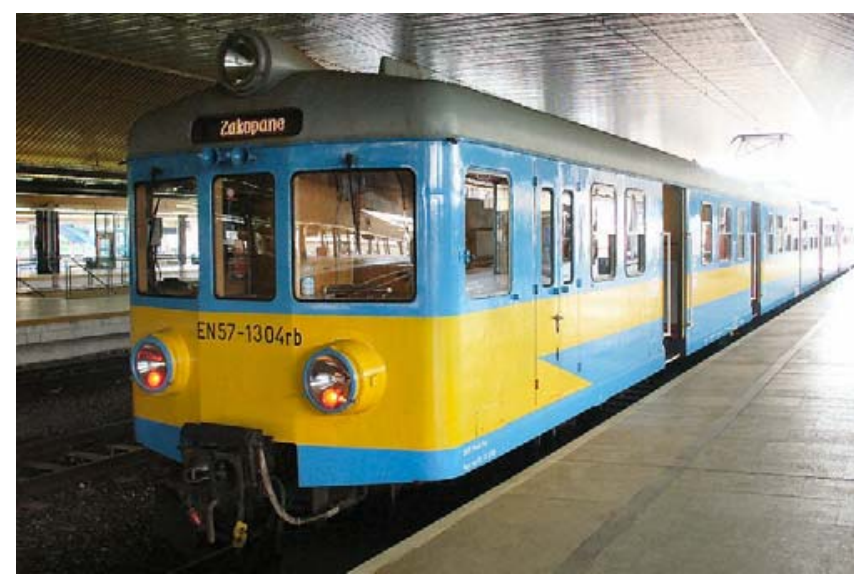

Rys.2. Elektryczny czteroczłonowy zespół trakcyjny serii EN71

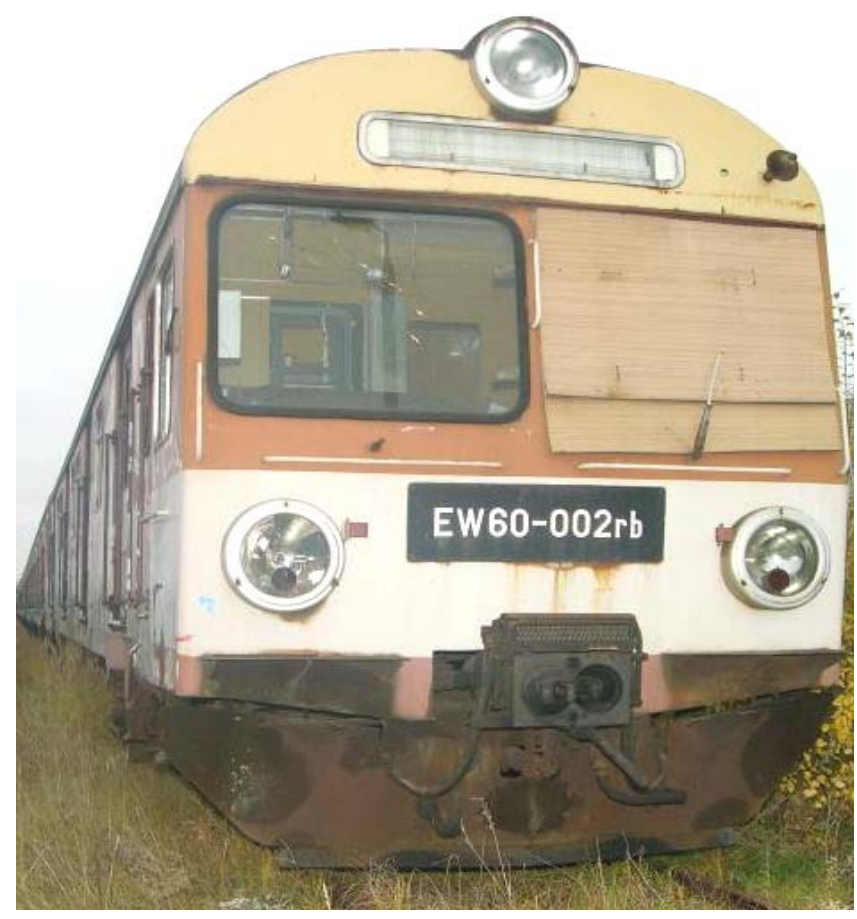

Rys.3. Elektryczny trójczłonowy zespół trakcyjny serii EW60

W dalszej części artykułu zaprezentowano ogólny i szczegółowy zakres modernizacji oraz zamierzenia modernizacyjne.
2. Ogólny zakres modernizacji zrealizowanej w ezt EN57, EN71 i EW60

2.1. Modernizacja elektrycznych zespołów trakcyjnych serii EN57 dla PKP „Przewozy Regionalne" (w ramach SPOT)

Elektryczne zespoły trakcyjne EN57 zostały zmodernizowane w ramach Sektorowego Programu Operacyjnego „Transport” (SPOT), finansowanego w dużej części z funduszy unijnych.

W procesie modernizacji uczestniczyły trzy zakłady: „Pesa” Bydgoszcz, „Newag” Nowy Sącz oraz ZNTK „Mińsk Mazowiecki” [1].

Ogólny zakres modernizacji obejmował:

- montaż przetwornicy statycznej z wyjściem $3 \times 400 \mathrm{~V}$ AC oraz $24 \mathrm{~V}$ i $110 \mathrm{~V}$ DC w miejsce zespołu elektromaszynowego

- montaż sprężarki śrubowej zasilanej napięciem $\mathrm{AC} 3 \mathrm{x} 400 \mathrm{~V}$

- modernizację wózków napędowych i tocznych wg dokumentacji konstrukcyjnej opracowanej przez Instytut Pojazdów Szynowych „Tabor’ w Poznaniu [2]

- zabudowę nowych modułowych kabin sanitarnych WC (wykonanych z laminatu poliestrowoszklanego) z instalacją wodna sterowaną elektrozaworami oraz ze zbiornikiem wody podgrzewanym elektrycznie i tzw. „suchą” instalację doprowadzającą wodę do muszli ustępowej i umywalki

- zamontowanie $\mathrm{w}$ przedziałach pasażerskich nowych siedzeń

- zastosowanie nowego wystroju wnętrz wagonów, w tym: panelowych ścian wewnętrznych i paneli sufitowych $\mathrm{z}$ laminowanych tworzyw sztucznych, opraw oświetleniowych tworzących linię świetlną, wpuszczonych w panel sufitowy, stolików podokiennych z tworzyw sztucznych, trudnościeralnej wykładziny podłogowej zgrzewanej na złączeniach oraz wywiniętej na ścianę na wysokość $10 \div 15 \mathrm{~cm}$ od poziomu podłogi wagonu

- przemieszczenie rur osłonowych przewodów elektrycznych biegnących wzdłuż całego e.z.t $z$ dachu wagonów do wnętrza - rury osłonowe „ułożone" pod sufitem przykryte panelami sufitowymi

- zamontowanie złącz międzywagonowych ułatwiających łączenie i rozłączanie wagonów zespołu w miejsce dotychczasowych skrzynek połączenia przewodów WN i NN

- zabudowę próżniowego wyłącznika szybkiego DCU

- zamontowanie elektronicznych tablic informacyjnych na czołach oraz na obu ścianach bocznych wagonu silnikowego

- zmianę układu sterowania drzwiami zewnętrznymi wejściowymi 
- zamontowanie elektrogrzejnych szyb czołowych w kabinie maszynisty

- zamontowanie elektrycznych wycieraczek szyb czołowych w kabinie maszynisty

- zamontowanie zmodernizowanych płytek sterujących wałem kułakowym

- zabudowę zmodernizowanych zderzaków międzywagonowych

- unowocześnienie czoła e.z.t. poprzez zastosowanie prefabrykowanego panelu o opływowym kształcie $\mathrm{w}$ połączeniu $\mathrm{z}$ modernizacją kabiny maszynisty tj. przesunięciem tylnej ściany kabiny maszynisty, likwidację bocznych drzwi wejściowych do przedziału dla podróżnych $z$ większym bagażem, zabudowę drzwi zewnętrznych wejściowych bezpośrednio do wnętrza kabiny maszynisty, modernizacje pulpitu maszynisty, montaż ergonomicznego fotela maszynisty, zabudowę nowych wzmocnionych drzwi z kabiny maszynisty do przedziału ze stojakami na rowery, montaż nowych osłon przeciwsłonecznych

- modernizację przedziału dla podróżnych z większym bagażem, w tym: likwidacja ścianki działowej pomiędzy przedsionkiem a przedziałem, zmiana rozmieszczenia siedzeń i grzejników, przystosowanie przedziału do przewozu rowerów, skrzynek sterujących indywidualnym otwieraniem i zamykaniem zewnętrznych drzwi wejściowych do zespołu

- zabudowę w wagonie „rb” (pierwsze drzwi automatyczne od strony kabiny maszynisty) lekkiego pomostu (wykonanego w zasadniczej części z niepalnego tworzywa) umożliwiającego wjazd z obu stron wagonu osobie niepełnosprawnej na wózku inwalidzkim

- zabudowę systemu monitorowania wnętrza pojazdu z odbiorem wizji w kabinie maszynisty, z możliwością cyfrowej rejestracji obrazu przez okres co najmniej 48 godzin

- zabudowę drzwi międzywagonowych o zwiększonej powierzchni przeszkolonej oraz drzwi oddzielających przedsionki od przedziałów pasażerskich wykonanych $\mathrm{z}$ ramy metalowej $\mathrm{i}$ całkowicie przeszklonych.

Ogółem na potrzeby PKP „Przewozy Regionalne” zmodernizowano 75 sztuk trójczłonowych zespołów.

\subsection{Modernizacja elektrycznych zespołów trakcyj- nych serii EW60 (6WEb) dla Kolei Mazowiec- kich}

Zespoły EW60 zostały zaprojektowane przez OBRPS Poznań w początkach lat osiemdziesiątych, a wykonane przez „Pafawag” Wrocław na przełomie lat $80 \mathrm{i}$ 90-tych. Wykonano tylko dwie sztuki, które weszły do eksploatacji pod koniec 1993 roku na torach Szybkiej Kolei Miejskiej w Trójmieście, gdzie z przerwa- mi były używane do końca 2000 r., a później odstawione do naprawy której nie wykonano. Nie używane przez pięć lat zespoły zostały zakupione przez Spółkę „Koleje Mazowieckie”, która borykała się z brakiem taboru i poddane kompleksowej modernizacji w ZNTK „Mińsk Mazowiecki”.

Ogólny zakres modernizacji obejmował $[5,6]$ :

- zastosowanie rozruchu impulsowego firmy Medcom

- zastosowanie tablic pneumatycznych

- wprowadzenie programu sterowania aparatami tablicowymi i systemami współpracy hamulca elektrodynamicznego z pneumatycznym

- modernizację układu hamulcowego na wózkach z zastosowaniem hamulca postojowego

- kompleksową modernizację kabiny maszynisty (pulpit, fotel, wystrój)

- zainstalowanie elektronicznego szybkościomierza rejestrującego

- zabudowę klimatyzacji kabin maszynisty $\mathrm{z}$ realizacja nawiewu ciepłego powietrza na szyby maszynisty

- zabudowę elektrycznych wycieraczek szyb czołowych ze spryskiwaczem

- zabudowę reflektorów halogenowych

- wykonanie wymuszonej wentylacji silników trakcyjnych z możliwością podgrzewania powietrza w zimie przed uruchomieniem zespołu

- zainstalowanie przetwornicy statycznej

- zainstalowanie próżniowego wyłącznika szybkiego DCU

- zainstalowanie sprężarki śrubowej

- zainstalowanie baterii akumulatorów zasadowych niklowo-kadmowych w technologii włóknistej o pojemności 100Ah

- zainstalowanie szybkozłącza międzywagonowego

- zainstalowanie monitoringu

- zainstalowanie urządzeń do informacji wizualnej i akustycznej

- zainstalowanie zabudowanego oświetlenia sufitowego

- wymianę okien na pakietowe

- zainstalowanie systemu indywidualnego otwierania drzwi z czasowym samoczynnym zamykaniem

- zainstalowanie napędu pneumatycznego do drzwi przejściowych z wagonu do wagonu

- zastosowanie nowego panelowego wystroju ścian z laminatów poliestrowo-szklanych

- zainstalowanie przezroczystych ścianek z poliwęglanu oddzielające przedsionek od przedziału

- wykonanie podłogi z wykładziny trudnościeralnej 
- zainstalowanie foteli wandaloodpornych w przedziałach pasażerskich

- wymianę izolacji termicznej i akustycznej

- zainstalowanie ogrzewania nawiewnego

- zainstalowanie kabiny WC $\mathrm{z}$ obiegiem zamkniętym w rozwiązaniu dla niepełnosprawnych

- zainstalowanie stojaków na rowery

- zainstalowanie urządzeń umożliwiających wjazd niepełnosprawnym.

Oba zmodernizowane zespoły EW60 (6WEb) znajdują się obecnie w eksploatacji spółki „Koleje Mazowieckie" na torach $\mathrm{z}$ wysokimi peronami.

\subsection{Modernizacja elektrycznych zespołów trak- cyjnych serii EN57 dla Kolei Mazowieckich (EN57KM)}

Zmodernizowane zespoły trakcyjne serii EN57KM zostały wykonane na potrzeby eksploatacyjne spółki „Koleje Mazowieckie”. Ogółem zmodernizowano pięć zespołów, a zakres modernizacji podobny był do wykonanego dla zespołu EN57-SPOT dla PKP Przewozy Regionalne.

Nowymi rozwiązaniami zastosowanymi $\mathrm{w}$ zespole EN57KM, które nie występują w EN57-SPOT są [9]:

- zastosowanie rozruchu impulsowego współpracującego $\mathrm{z}$ hamowaniem elektrodynamicznym (z rekuperacją)

- zabudowa układu klimatyzacji kabiny maszynisty

- modernizacja układu mechanicznego hamulca na wózkach

- zastosowanie układu współpracy hamulca elektropneumatycznego $\mathrm{z}$ hamulcem elektrodynamicznym

- zabudowa ogrzewania nawiewnego

- zainstalowanie elektronicznego szybkościomierza rejestrującego

- zainstalowanie licznika energii do pomiaru całkowitej energii pobieranej oraz oddanej do sieci

- wykonanie wymuszonej wentylacji silników trakcyjnych z możliwością podgrzewania powietrza $\mathrm{w}$ zimie przed uruchomieniem zespołu. Ogółem dotychczas wykonano tylko dwa zmodernizowane zespoły.

\subsection{Modernizacja elektrycznego zespołu trakcyj- nego serii EN71 dla Kolei Mazowieckich}

Zmodernizowany czterowagonowy elektryczny zespół trakcyjny serii EN71 został wykonany na potrzeby spółki „Koleje Mazowieckie”. Ogółem zmodernizowano tylko jeden zespół, a zakres modernizacji był w zasadzie identyczny jak dla zespołu serii EN57-SPOT. Nowymi urządzeniami w zespole EN71 (w stosunku do EN57-SPOT) były [8]:

- układ klimatyzacji kabiny maszynisty

- międzywagonowe złącza elektryczne i pneumatyczne
- elektroniczny szybkościomierz rejestrujący

- licznik energii

- baterie akumulatorów o zwiększonej pojemności.

\subsection{Modernizacja elektrycznych zespołów trak- cyjnych serii EN57 SKM}

Elektryczny zespół trakcyjny serii EN57 został zmodernizowany na potrzeby eksploatacyjne Szybkiej Kolei Miejskiej w Trójmieście.

Zakres modernizacji był podobny jak zespołów EW60 i EN57KM oraz EN57-SPOT i EN71 za wyjątkiem rozruchu impulsowego i układów współpracy hamulca pneumatycznego $\mathrm{z}$ hamulcem elektrodynamicznym. W odróżnieniu od EN57KM w zespole EN57 SKM zastosowano układ rozruchu impulsowego wykonany przez Instytut Elektrotechniki z Warszawy.

Dodatkowo zastosowany układ sterowania umożliwia pracę w trakcji wielokrotnej „klasycznych” i zmodernizowanych zespołów trakcyjnych [12]. Ogółem procesowi modernizacji poddano cztery zespoły.

Widoki wszystkich zmodernizowanych zespołów przedstawiono na rys. $4 \div 8$.

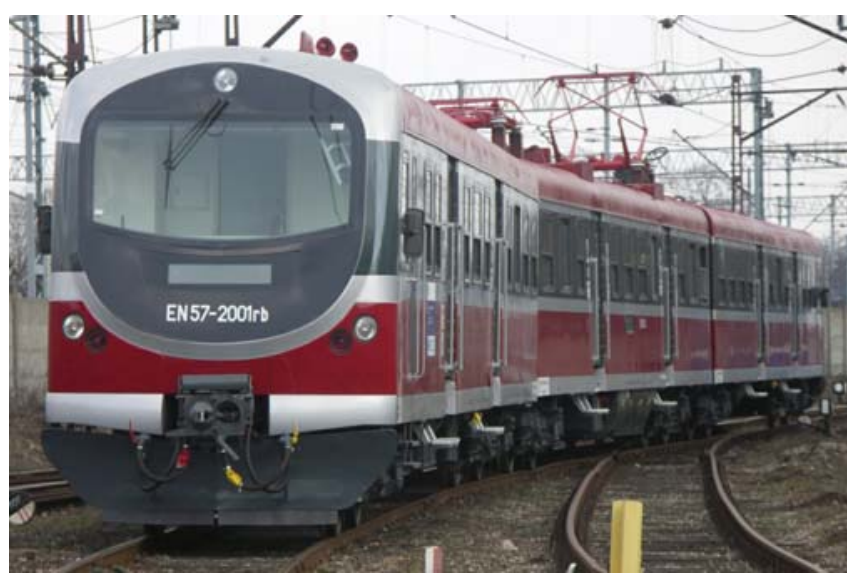

Rys.4. Elektryczny zespół trakcyjny serii EN57 zmodernizowany w ramach Sektorowego Programu Operacyjnego Transport na potrzeby PKP Przewozy Regionalne

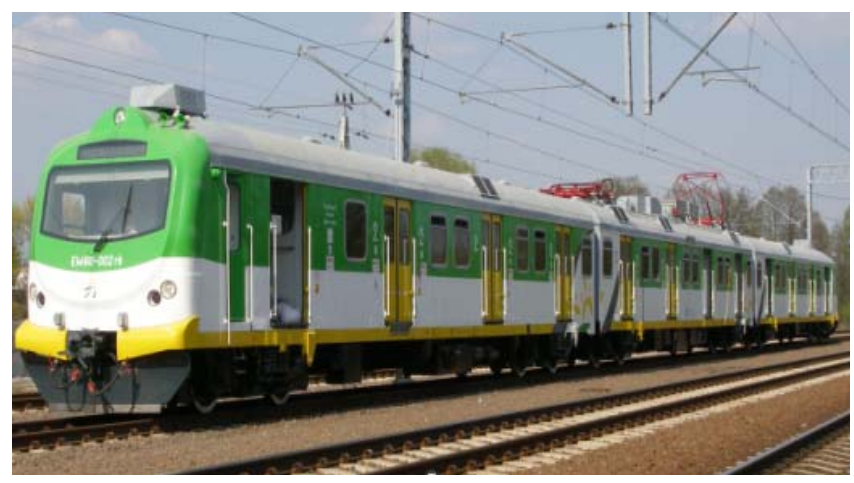

Rys.5. Elektryczny trójczłonowy zespół trakcyjny serii EW60 (6WEb) zmodernizowany dla Kolei Mazowieckich 


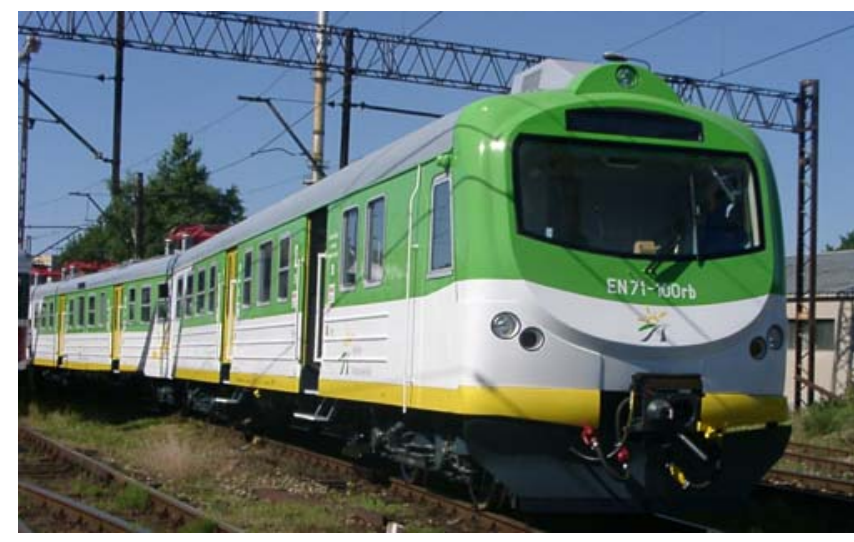

Rys.6. Elektryczny trójczłonowy zespół trakcyjny serii EN57 zmodernizowany dla Kolei Mazowieckich

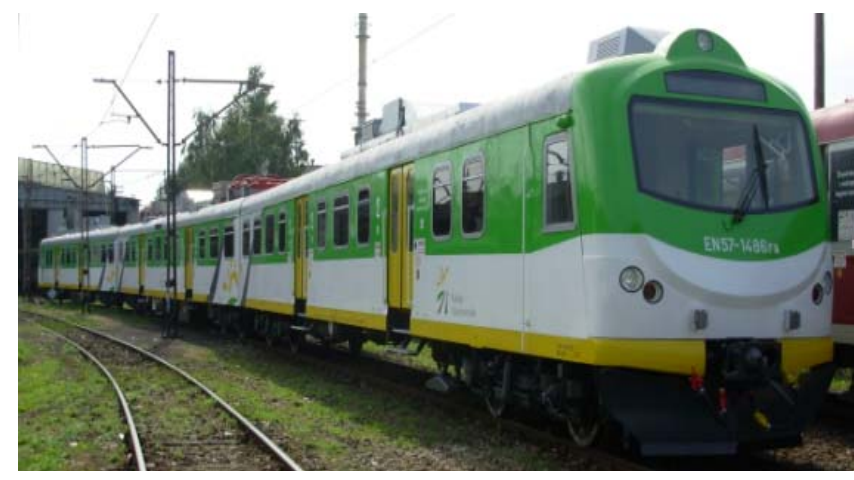

Rys.7. Elektryczny czteroczłonowy zespół trakcyjny EN71 zmodernizowany dla Kolei Mazowieckich

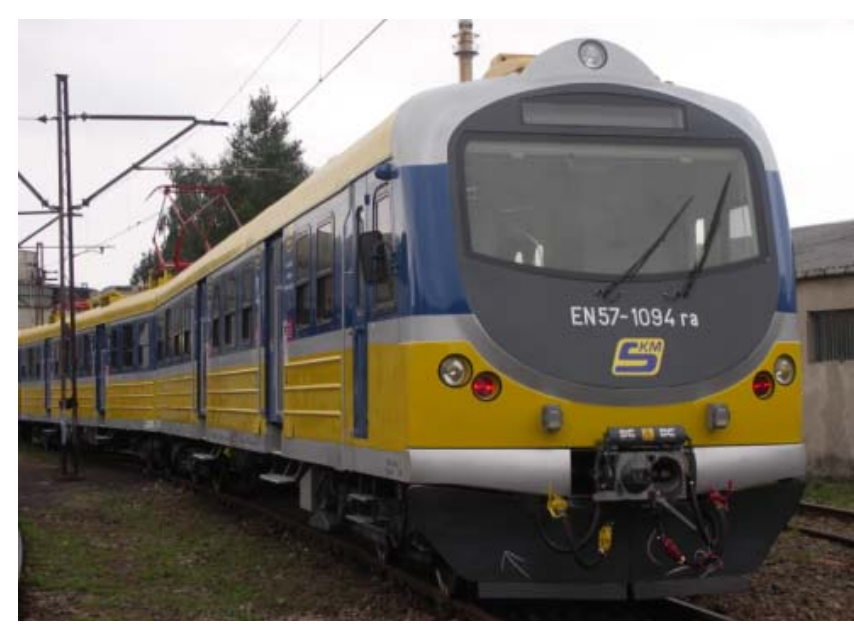

Rys.8. Elektryczny trójczłonowy zespół trakcyjny EN57 zmodernizowany dla Szybkiej Kolei Miejskiej w Trójmieście

3. Opisy ważniejszych zmodernizowanych układów, systemów i nowych zespołów

Wśród wielu zmodernizowanych układów i zespołów wymienić należy:

- w części mechanicznej

- wózki napędne i toczne

- czoło zespołu

- kabiny sterownicze, wnętrza przedziałów pasażerskich oraz kabin sanitarnych

- układy pneumatyczne oraz układy hamulca

- układ klimatyzacji (schładzacze)
- w części elektrycznej

- choperowy napęd trakcyjny

- próżniowy wyłącznik szybki

- przetwornica statyczna.

Dalszą część artykułu poświęcona będzie opisom wybranych ważniejszych zmodernizowanych układów i nowych zespołów.

Modernizacja wózków tocznych i napędnych dla zespolów EN57 i EN71 miała na celu poprawę jakości biegu (pogarszającego się w miarę zużywania się elementów układu biegowego) oraz eliminację jego awaryjności wynikającej z wad widłowego prowadzenia maźnic.

Ostatecznie w wózkach zastosowano w pierwszym stopniu usprężynowania sprężyny gumowo-metalowe (początkowo z firmy Conti Tech z Niemiec, a w produkcji seryjnej z firmy Intergum - Środa Wlkp) spełniające również funkcję prowadzenia zestawów kołowych. Ponadto dla przeprowadzenia prób wprowadzono maźnice skrzydełkowe w wersji spawanej, a docelowo w wersji z korpusem odlewanym.

Wynikiem wprowadzonej modernizacji było uzyskanie bezluzowego prowadzenia zestawów kołowych $\mathrm{w}$ ramie wózka, a tym samym eliminacja usprężynowania pierwszego stopnia za pośrednictwem resoru piórowego i prowadzenia widłowego [2].

Ogólny widok wózka przed i po modernizacji zaprezentowano na rys. 9.

a)
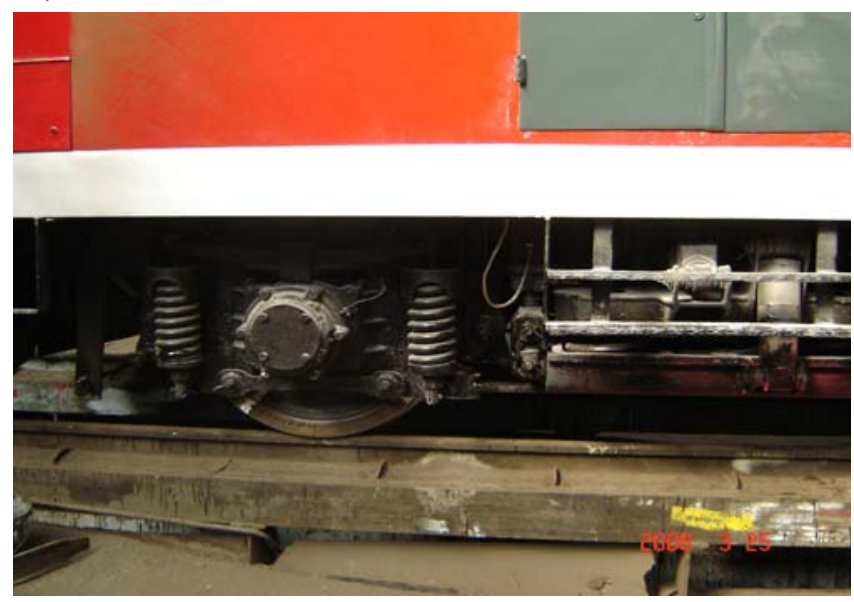

(b)

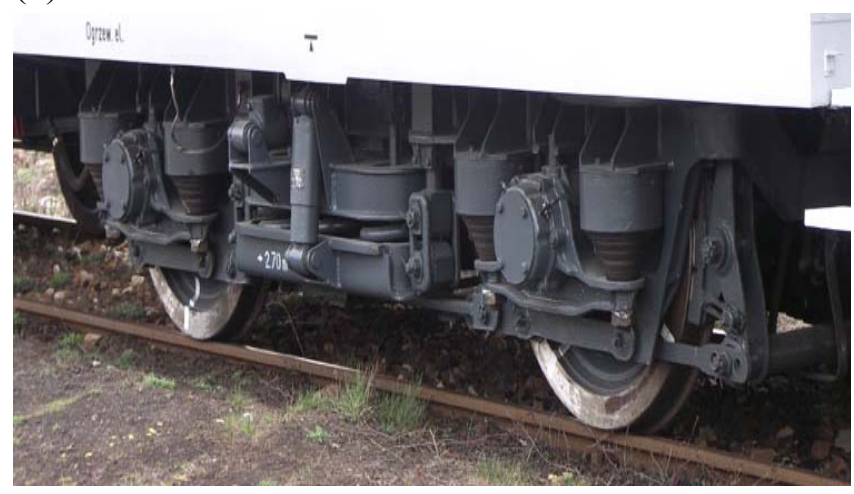

Rys.9. Widok wózka przed (a) i po modernizacji (b) 
Dla zespołu EW60 (6WEb) nie dokonywano żadnych zmian w układzie biegowym i konstrukcji wózka w stosunku do pierwotnych zespołów [5, 6].

\section{Zmiana konstrukcji i ksztaltu czoła}

Wszystkie zmodernizowane zespoły uzyskały nową konstrukcję czoła wykonaną z laminatu poliestrowoszklanego o grubości $8 \mathrm{~mm}$. Kształt czoła odpowiada współczesnym trendom stylistyki pojazdów kolejowych, a samo czoło składa się ze szkieletu wykonanego jako konstrukcja spawana $\mathrm{z}$ blach i kształtowników (przygotowana tak, by stanowić ochronę w przypadku zderzenia), szyby czołowej elektrogrzewczej trójwarstwowej klejonej $\mathrm{z}$ wkładkami foliowymi, tablicy informacyjnej, wycieraczek i spryskiwaczy elektrycznych oraz halogenowych projektorów i lamp sygnałowych.

Widoki nowych kształtów czół przedstawiono rys. $4 \div 8$.

\section{Modernizacja kabin sterowniczych}

Kabiny sterownicze znajdujące się na końcach każdego zespołu połączone są z przedziałami pasażerskimi drzwiami umieszczonymi na ścianie tylnej.

$\mathrm{Na}$ pulpitach sterowniczych wykonanych jako konstrukcje spawane $z$ blach i profili stalowych oraz płyty z laminatu poliestrowo-szklanego zabudowano na panelach wszystkie urządzenia sterujące, wskazujące oraz przeznaczone do monitoringu.

W kabinie znajduje się również monitor podwieszony pod sufitem służący do obserwacji obrazu z kamer systemu monitoringu. Kabina ma elektryczne ogrzewanie montowane na ścianach bocznych oraz układ schładzacza zabudowany nad kabiną.

Ponadto w osi symetrii wagonu zamontowano regulowany ergonomiczny fotel umożliwiający dostosowanie go do wzrostu maszynisty. Wszystkie kabiny sterownicze zmodernizowanych zespołów są ergonomiczne, przestrzenne, wyizolowane cieplnie i akustycznie.

Widoki kabin sterowniczych przed i po modernizacji prezentują rys. $10 \mathrm{i} 11$.

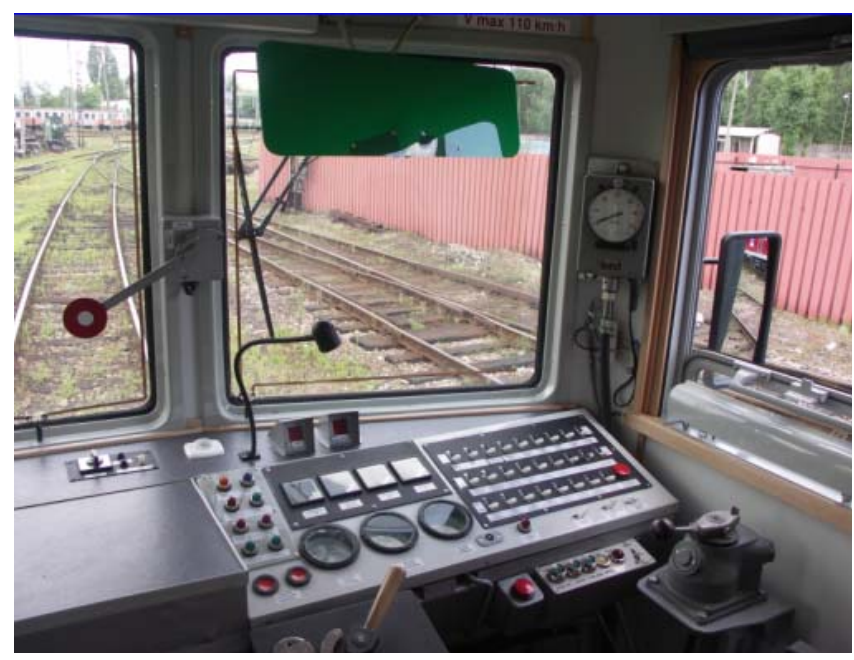

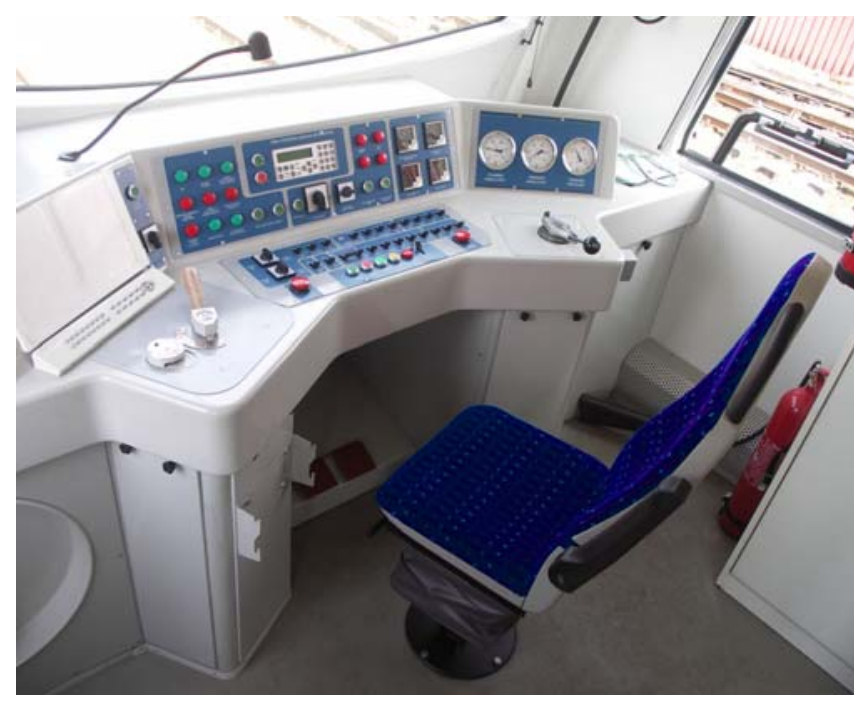

Rys.10. Widok na kabinę sterowniczą zespołu EN57 (stan przed i po modernizacji)

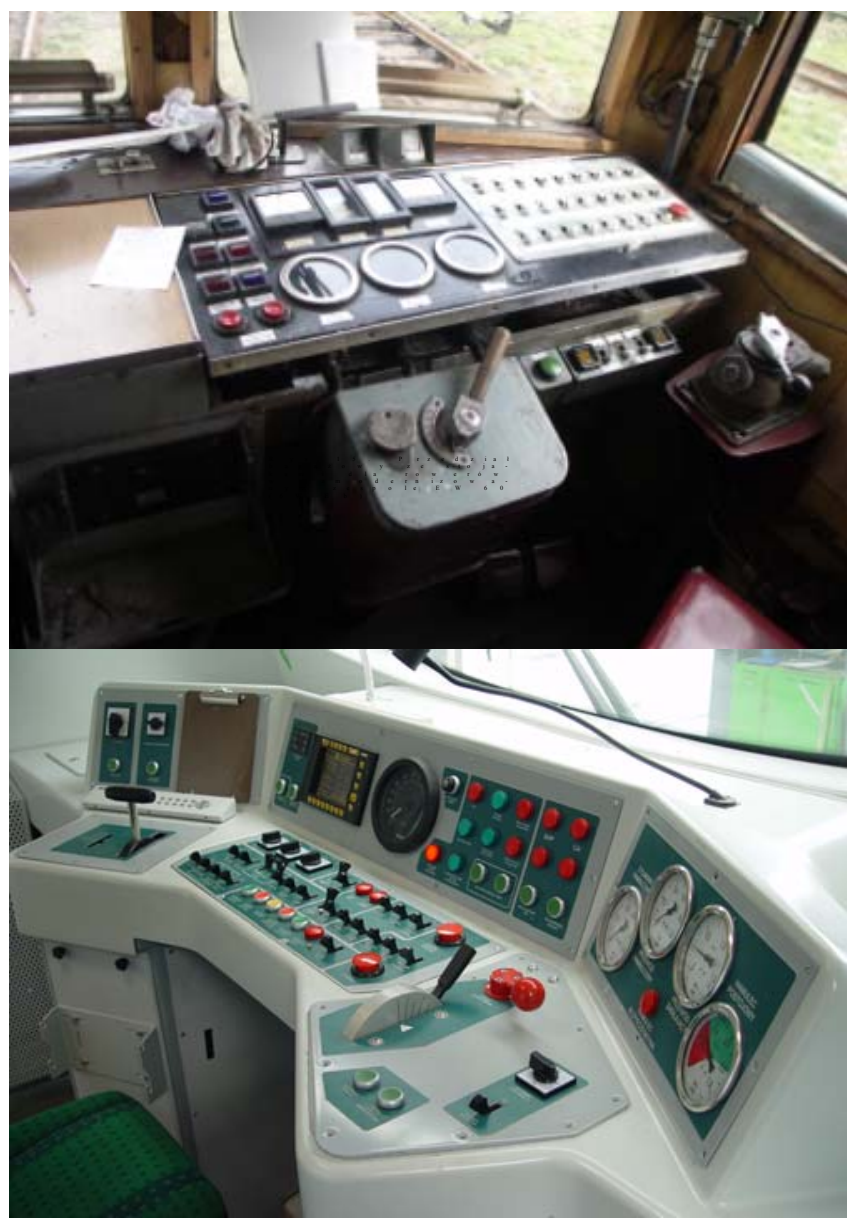

Rys.11. Widok na modernizowaną kabinę sterowniczą zespołu EW60 (stan przed i po modernizacji)

Modernizacja przedzialów pasażerskich i kabin sanitarnych

Wyposażenie i rozplanowanie wnętrz przedziałów pasażerskich jest przestronne i funkcjonalne, zapewniające łatwe przemieszczanie się pasażerów (nawet w okresie szczytu komunikacyjnego). W przedziałach zastosowano siedzenia podwójne, siedzenia pojedyncze i siedzenia odchylne, a dla osób niepełnosprawnych siedzenia wyposażone w pasy bezwładnościowe 
do zapięcia pasażera na wózku inwalidzkim.

Półki bagażowe umieszczone zostały nad oknami, a w każdym przedziale poręcze poziome i pionowe. Między siedzeniami zabudowano stoliki z laminatu poliestrowo-szklanego oraz śmietniczki. Ponadto w przedziałach zabudowane zostały stojaki na rowery oraz rampy umożliwiające wjazd osobom niepełnosprawnym.

W ścianach bocznych poszczególnych wagonów zastosowano okna pakietowe uchylne a na każdej ze ścian po jednym oknie bezpieczeństwa. Również po każdej stronie EN57 i EW71 znajdują się po dwie pary drzwi, a w EW60 po cztery pary drzwi.

Do ogrzania wagonów zastosowano ogrzewanie nawiewne, a na sufitach zamonotowano głośniki oraz linie świetlne. W każdym zespole znajduje się przedział sanitarny wyposażony w muszlę, siedzenie, umywalkę, lustra, zasobniki i dozowniki, kosz i półkę podręczna. Wnętrze przedziału przystosowane jest do korzystania przez osoby niepełnosprawne. Ze wzglę$\mathrm{du}$ na eksploatację $\mathrm{w}$ obrębie aglomeracji przedział sanitarny wyposażony jest obligatoryjnie $\mathrm{w}$ system ubikacji z obiegiem zamkniętym.

Wnętrze przedziałów pasażerskich i sanitarnych wyłożone są panelami wykonanymi z laminatu poliestrowo-szklanego. Ponadto ściany i dach pokryte są masą dźwiękochłonną i ocieplone wełną mineralną, a podłogi pokryte masą dźwiękochłonną, wyłożoną sklejką i antypoślizgową wykładziną.

Widoki zmodernizowanych przedziałów pasażerskich, sanitarnych i bagażowych przedstawiono na rys. $12 \div 18$

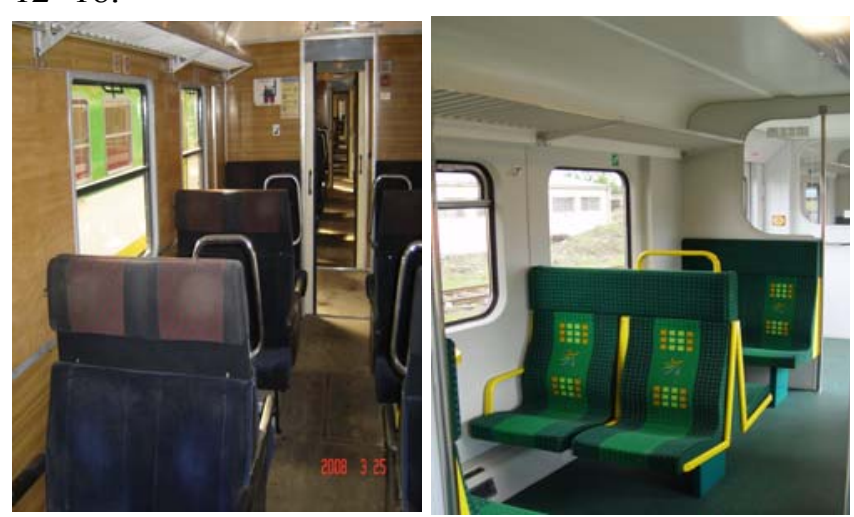

Rys.12. Widok na przedział pasażerski przed i po modernizacji zespołu EW60 (6WEb)
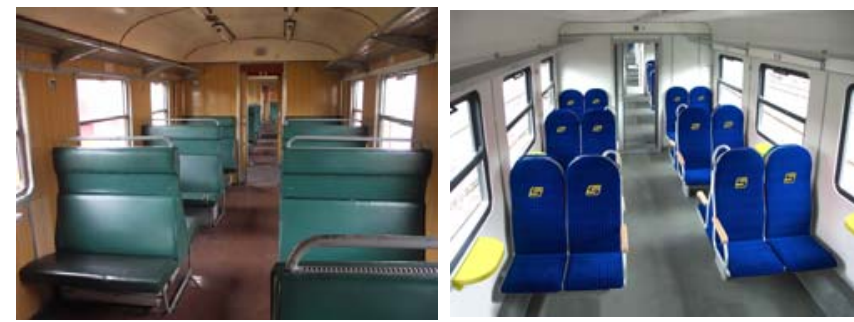

Rys.13. Widok na przedział pasażerski przed i po modernizacji zespołu EN57SKM

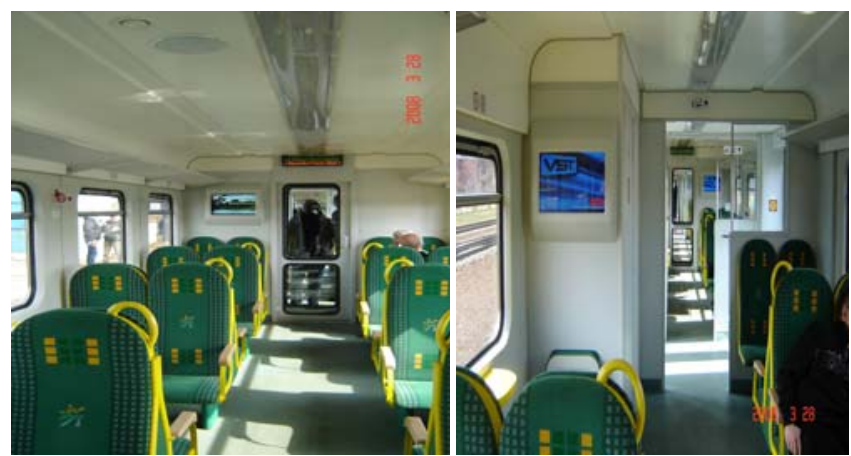

Rys.14. Widok na przedział pasażerski po modernizacji zespołu EN57KM

Rys. 15. Przedział bagażowy ze stojakami dla rowerów w zmodernizowanym zespole EW60 $(6 \mathrm{WEb})$
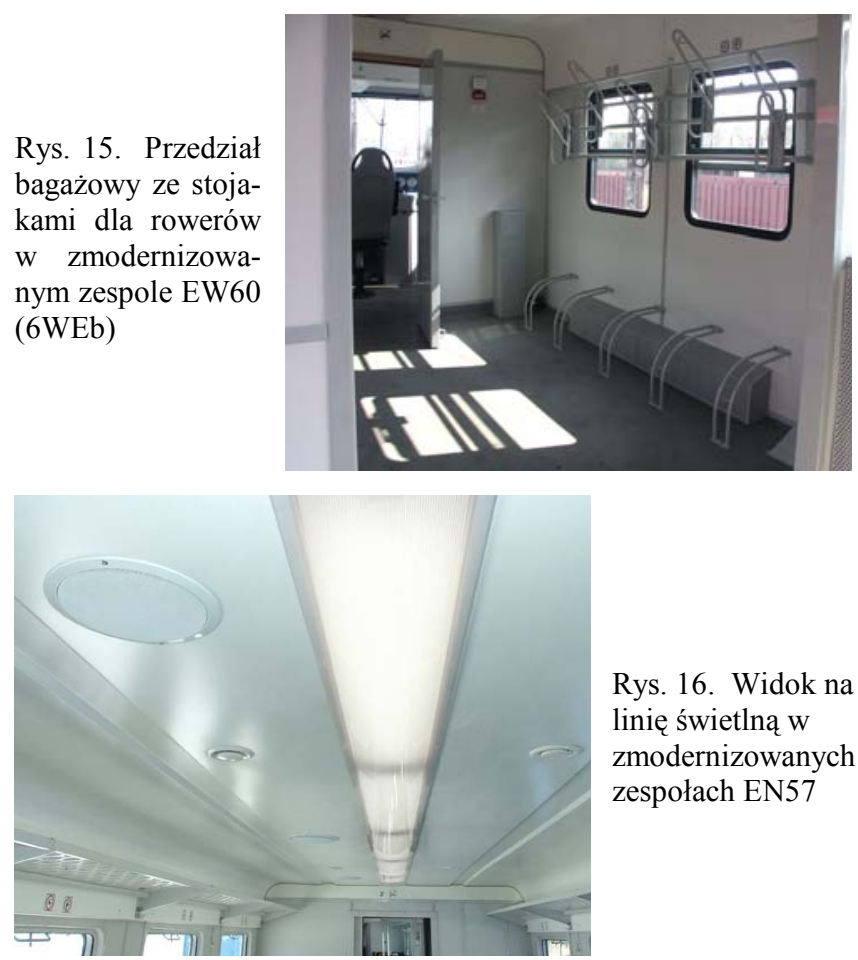

Rys. 16. Widok na linię świetlną w zmodernizowanych zespołach EN57

Rys. 17. Widok na przedział sanitarny zespołu EN57KM
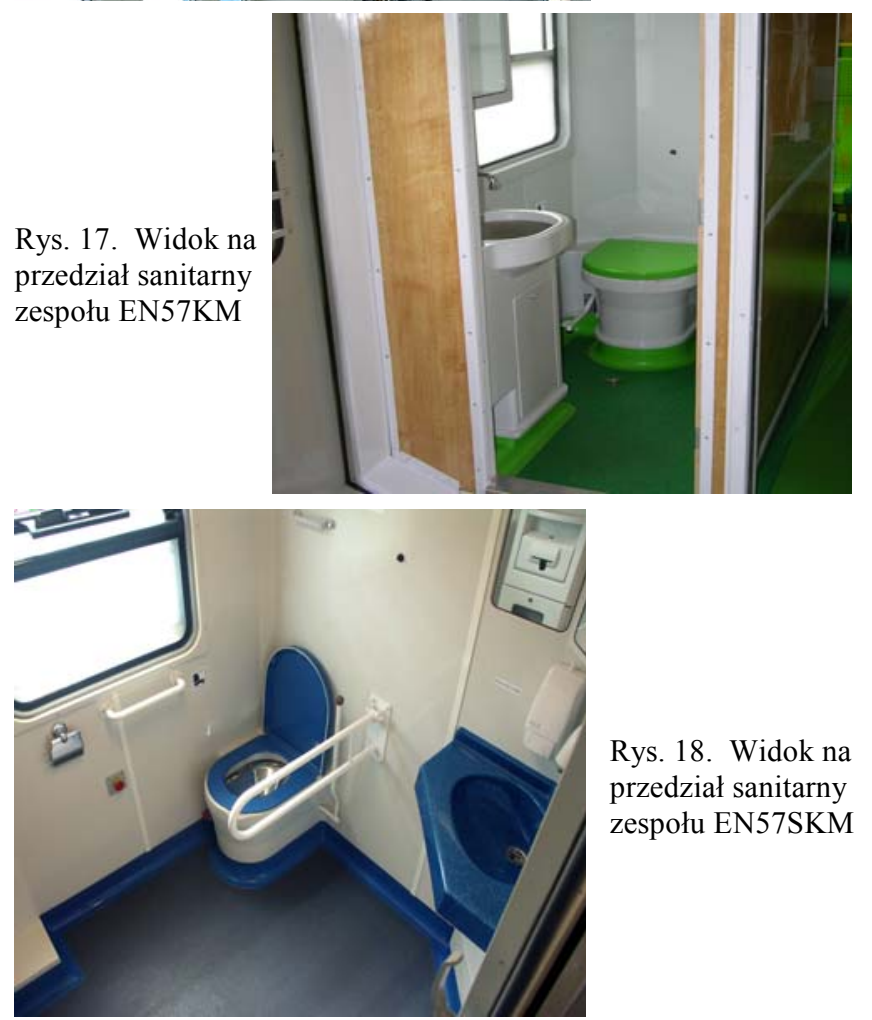

Rys. 18. Widok na przedział sanitarny zespołu EN57SKM 


\section{Modernizacja ukladu pneumatycznego hamulca}

Układy pneumatyczne każdego ze zmodernizowanych zespołów składają się z układów: zasilającego, hamulca, blokady pneumatycznej szaf WN i SN, zasilania i sterowania drzwiami automatycznymi oraz zasilania pneumatycznych urządzeń pomocniczych w tym odbieraka prądu.

W układzie zasilającym zastosowano nowoczesny agregat spreżarkowy ze sprężarką śrubową o wydajności $60 \mathrm{~m}^{3} / \mathrm{h}$, zbiorniki powietrza oraz filtry oczyszczające sprężone powietrze $\mathrm{z}$ oleju.

Widok na zabudowany agregat sprężarkowy pod ostoją jednego zespołu przedstawiono na rys. 19 .

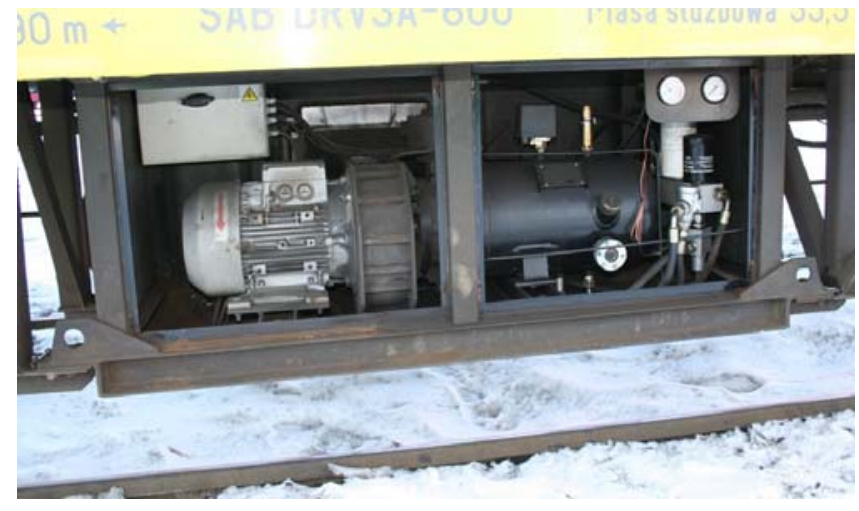

Rys. 19. Widok na zabudowany agregat sprężarkowy

Do podnoszenia odbieraków prądu zastosowany został pomocniczy agregat sprężarkowy z przekaźnikiem, zaworem zwrotnym, zbiornikiem, odoliwiaczem i kurkiem odcinającym. Agregat jest zasilany z baterii akumulatorów.

Układy hamulcowe zastosowane w zmodernizowanych zespołach są zróżnicowane.

W zespole EW60 (6WEb) zastosowano typowy, nowoczesny układ zabudowany na tablicy aparatów pneumatycznych i elektropneumatycznych ze sterowaniem za pośrednictwem sygnałów elektrycznych (wykonane $\mathrm{w}$ technice mikroprocesorowej), redundancją sterowania (w przypadku awarii sterowania mikroprocesorowego uaktywnia się samoczynne sterowanie pneumatyczne).

Układ umożliwia sterowanie współpracą hamulca elektrodynamicznego $\mathrm{z}$ hamulcem elektropneumatycznym typu bezpośredniego.

Widok na zabudowaną tablicę pneumatyczną w zmodernizowanym zespole EW60 (6WEb) przedstawiono na rys. 20.

W zmodernizowanych zespołach EN57KM zastosowano hamulec elektropneumatyczny systemu Oerlikon, który jest połączeniem hamulca samoczynnego przy sterowaniu pneumatycznym $\mathrm{z}$ hamulcem bezpośrednim przy sterowaniu elektrycznym. Hamulec ten umożliwia współpracę zespołu z zespołami wyposażonymi w hamulec systemu Knorra.

Dokładne opisy układów hamulcowych i ich zasad sterowania znajdują się w pracach $[7 \div 10]$.

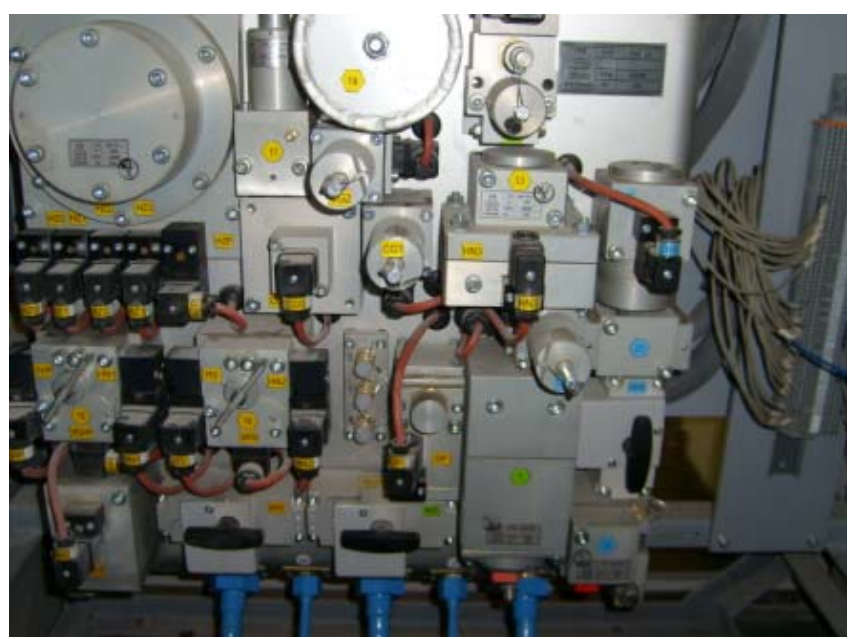

Rys. 20. Widok na tablicę aparatów elektropneumatycznych i pneumatycznych w zmodernizowanym zespole EW60

Dla zabezpieczenia szaf (skrzyni) WN i SN zastosowano blokady pneumatyczne wyposażone w zawory blokujące, których trzony tłokowe stanowią część mechanizmu ryglującego. Do zamykania bocznych drzwi najczęściej służą aparaty napędowe zasilane sprężonym powietrzem poprzez kurek odcinający, filtr powietrza oraz zawór redukcyjny.

W układzie pneumatycznym poszczególnych drzwi znajduje się aparat napędowy, płyta pneumatyczna z zaworem odcinającym, filtrem, elektrozaworami otwierania drzwi i blokady pneumatycznej oraz zawór ręczny otwierania awaryjnego.

W układzie urządzeń pomocniczych znajdują się syreny nisko- i wysokotonowe usytuowane na dachu nad kabiną sterowniczą. Uruchomienie syren odbywa się przez nożny, podwójny zawór przyciskowy.

\section{Układ schladzania}

Każdy ze zmodernizowanych zespołów wyposażony został w schładzacz dachowy służący do osiagnięcia $i$ utrzymania $\mathrm{w}$ czasie pracy $\mathrm{w}$ kabinie sterowniczej temperatury w zakresie $20 \div 25^{\circ} \mathrm{C}$ przy temperaturze zewnętrznej dochodzącej do $+45^{\circ} \mathrm{C}$ oraz recylkulacji powietrza w kabinie.

Praca schładzacza przebiega w cyklu automatycznym na podstawie parametrów (wymaganej temperatury i wydajności wentylatorów) zaprogramowanych przez użytkownika w sterowniku. Znamionowa moc chłodzenia oraz wymagany max. wydatek powietrza zapewniają właściwy mikroklimat $\mathrm{w}$ kabinie sterowniczej.

Opisy pozostałych zmodernizowanych układów, systemów i zespołów przedstawiono szczegółowo w poszczególnych dokumentacjach techniczno-ruchowych producentów i dostawców $[6 \div 10]$.

\section{Choperowy napęd trakcyjny}

W zmodernizowanym zespole EW60 (6WEb) zastosowano napęd trakcyjny CT600-3000 składający się z dwóch choperów tranzystorowych CZT600-3000, 
silników trakcyjnych z czujnikami prędkości i temperatury oraz dławikiem sieciowym. Obwód główny zmodernizowanego zespołu składa się ponadto $\mathrm{z}$ dwóch odbieraków prądu, jednego odłącznika trakcyjnego i jednego wyłącznika szybkiego.

Przekształtniki tranzystorowe, dławiki sieciowe i silniki chłodzone sa powietrzem $\mathrm{z}$ wymuszeniem zewnętrznym.

Napęd trakcyjny CT600-3000 napędza cztery osie dwóch wózków trakcyjnych poprzez odbierak prądu, wyłącznik szybki i rozdzielnicę. Sterowanie odbywa się z pulpitu poprzez zadajnik jazdy i hamowania oraz ze sterownika nadrzędnego. Sterowanie napędem jest realizowane poprzez sterownik nadrzędny, który wypracowuje sygnały momentu rozruchowego i hamującego.

Rozdzielnica służy do łagodnego włączenia choperów zapewniających przetwarzanie napięcia wejściowego 3000V DC na napięcie regulowane wyjściowe stałe w zakresie od zera do napięcia zasilania. W trakcie hamowania przy napięciu powyżej $3850 \mathrm{~V}$ załączany jest rezystor hamowania rozpraszający energię kinetyczną podczas hamowania.

Nawrotnik trakcyjny zapewnia przełączanie kierunku przepływu prądu w uzwojeniach wzbudzenia silników trakcyjnych. Ostatnim ogniwem w układzie napędowym są silniki trakcyjne z zabudowanymi czujnikami prędkości umożliwiającymi wypracowanie prawidłowych sygnałów sterujących napędem, zapewniające detekcję poślizgu oraz chroniące silniki przed przegrzaniem i utratą właściwej izolacji.

W układzie napędowym zmodernizowanego zespołu EN57KM zastosowano dwa chopery trakcyjne tranzystorowe CT450-3000.

Pozostałe urządzenia, jak wyłącznik szybki, rozdzielnica, dławik, rezystor hamowania, silniki trakcyjne są skonfigurowane tak samo jak dla EW60 (6WEb). Szczegółowe opisy poszczególnych urządzeń znajdują się w pracach $[6 \div 10]$.

W odróżnieniu od układu napędowego zespołów EW60 i EN57KM dostarczonych przez firmę Medcom, w zmodernizowanych zespołach EN57SKM zastosowano układ do regulacji procesu rozruchu i hamowania wykonany przez Instytut Elektrotechniki - Warszawa.

Układ napędowy EN57SKM składa się z:

- podwójnego chopera wykonanego w technologii IGBT do regulacji rozruchu i hamowania elektrodynamicznego obcowzbudnego dwóch grup szeregowych silników prądu stałego

- filtrów wejściowych oraz przeciwzakłóceniowych

- układu hamowania elektrodynamicznego z rezystorami hamowania

- układu przeciwpoślizgowego

- rozdzielnicy WN z zabezpieczeniem nadprądowym i różnicowprą̧dowym
- system diagnostyki zespołu

- komputerowego sterownika zespołu

- terminala operatorskiego umieszczonego w pulpitach

- pulpitowych zadajników jazdy

- układu współpracy hamulca elektrodynamicznego $\mathrm{z}$ hamulcami pneumatycznymi zespołu

- układów sterowania wielokrotnego do współpracy z zespołem zmodernizowanym i z zespołem ,klasycznym” (przed modernizacja).

Zastosowany układ napędowy przewidziany został do realizacji następujących procesów:

- rozruch silników trakcyjnych dwóch równoległych grup zasilanych z czoperów

- rozruch lub hamowanie przy pracującej jednej grupie silników

- jazda do przodu z zadaną wartością prądu silników

- jazda do tyłu oraz jazda manewrowa

- hamowanie elektrodynamiczne

- współpraca hamowania elektrodynamicznego i pneumatycznego zespołu

- pełna wymiana informacji pomiędzy zespołami zmodernizowanymi i w połączeniu $\mathrm{z}$,klasycznymi" w jeździe wielokrotnej

- działanie przeciwpoślizgowe podczas rozruchu i hamowania

- zapewnienie poprawnej pracy w warunkach częstych rozruchów i hamowań.

Próżniowe wyłączniki prądu stałego DCU-400J i 630J przeznaczone są do taboru trakcji elektrycznej zasilanej napięciem $3 \mathrm{kV}$. Wyłączniki DCU działają na zasadzie wyłączania przeciwprądem, przy czym załączanie jak i wyłączanie odbywa się w komorze próżniowej. Źródłem energii wytwarzającej przeciwprąd i energii uruchamiającej napęd komór próżniowych są kondensatory.

Wyłącznik składa się z trzech zespołów powiązanych funkcjonalnie i połączonych elektrycznie lecz niezależnych mechanicznie: zespołu łączeniowego, zespołu kondensatora komutacyjnego i zespołu ogranicznika przepięć zewnętrznych. Wyłącznik jest sterowany za pomocą mikroprocesorowego sterownika ze światłowodowym systemem transmisji sygnałów między tym sterownikiem a współpracującymi z nim modułami elektronicznymi, czujnikami i innymi elementami obwodów wyłącznika.

\section{Przetwornica statyczna PSM-26NS}

Jest urządzeniem przeznaczonym do przetwarzania napięcia sieci trakcyjnej $3 \mathrm{kV}$ na napięcie stałe $(24 \mathrm{~V}$ i $110 \mathrm{~V})$ oraz przemienne $(3 \mathrm{x} 400 \mathrm{~V})$ wykorzystywane $\mathrm{w}$ instalacjach średniego i niskiego napięcia zmodernizowanych zespołów. Wyjściowe napięcie $3 \times 400 \mathrm{~V}$ może być również asymetryczne, co umożliwia zasilanie obwodów $230 \mathrm{~V}$. 
Przetwornica jest urządzeniem w pełni zautomatyzowanym i umożliwia ciągłe zasilanie obwodów niskiego napięcia niezależnie od aktualnego napięcia wejściowego $(2 \div 4 \mathrm{kV}$ i krótkotrwałym $1,8 \div 4,2 \mathrm{kV})$.

\section{Próby i badania zmodernizowanych elektrycz- nych zespolów trakcyjnych EN57, EW60 i EN71}

Zmodernizowane zespoły (przynajmniej jeden z każdej serii) zostały poddane próbom i badaniom odbiorczym oraz stacjonarnym i ruchowym.

Zakres prób i badań był zgodny z zakresem badań koniecznych wg Rozporządzenia Ministra Infrastruktury z dnia 12.10.2005r. (Dz. U. nr 212 poz.1772) i dotyczył sprawdzenia nowych i zmodernizowanych urządzeń i układów, które w istotny sposób mogłyby decydować o bezpieczeństwie ruchu i bezpieczeństwie przewożonych pasażerów.

Obejmował on w szczególności:

- sprawdzenie działania układów hamulca

- pomiary zakłóceń emitowanych przez zastosowane urządzenia impulsowe, w tym sprawdzenie oddziaływania zespołów na układy i systemy sterowania ruchem kolejowym

- sprawdzenie warunków podróżowania, w tym pomiary oświetlenia, ogrzewania, hałasu wewnętrznego i pola magnetycznego

- badania właściwości trakcyjnych.

Zakończone $\mathrm{z}$ wynikiem pozytywnym próby $\mathrm{i}$ badania pozwoliły na wystapienie do Urzędu Transportu Kolejowego $\mathrm{z}$ wnioskiem o wydanie terminowego świadectwa typu pojazdu kolejowego.

Wszystkie zmodernizowane zespoły uzyskały świadectwa dopuszczenia do eksploatacji, przy czym zespoły EN57-SPOT i EN71 bezterminowe natomiast EN57KM, EW60 i EN57SKM terminowe na czas realizacji prób eksploatacyjnych (eksploatacji obserwowanej), której zakończenie zaplanowano w połowie 2009 roku.

\section{Podsumowanie}

Przedstawiony $\mathrm{w}$ artykule zakres modernizacji elektrycznych zespołów trakcyjnych produkowanych wcześniej przez Fabrykę Wagonów „Pafawag” Wrocław obejmuje w zasadzie wszystkie ważniejsze układy i systemy za wyjątkiem silników trakcyjnych.

Można stwierdzić, że prezentowane modernizacje są rozwiązaniami kompleksowymi, które od wielu lat przechodziły fazy koncepcji, założeń i projektów technicznych. Wdrażany zakres modernizacji nadał z jednej strony nowocześniejszy wygląd zespołom, z drugiej natomiast dzięki wprowadzonym zmianom $\mathrm{w}$ układzie rozruchu i hamowania pozwolił na uzyskanie lepszych charakterystyk trakcyjnych.

Dalszymi ważniejszymi zamierzeniami czekającymi na rozwiązania to:
- zastosowanie asynchronicznych silników trakcyjnych (w dotychczasowej obudowie silników prądu stałego)

- wprowadzenie nowych układów przekształtnikowo-falownikowych do zasilania silników trakcyjnych

- modernizacja oparcia pudła na wózkach (drugi stopień zawieszenia)

- modernizacja zawieszenia silników trakcyjnych i przekładni osiowych.

Należy również zaznaczyć, że modernizacja taboru szynowego ma wiele uwarunkowań, z których najważniejsze to:

- ograniczone środki finansowe na realizację prac

- koszt jako jedyne kryterium wyboru rozwiazzań opartych tylko na cenach głównych zespołów, układów, aparatów i urządzeń

- krótkie okresy realizacji modernizacji (najcześciej zamawiający żąda realizacji w ciagu jednego roku)

- dhugotrwałe procedury przetargowe

- objęcie próbami eksploatacyjnymi wszystkich zmodernizowanych pojazdów co wpływa na koszt przedsięwzięcia

- zmiany przez zamawiającego zakresu modernizacji w trakcie realizacji prac

- nieciagłości programów modernizacyjnych

- ograniczona oferta poddostawców oraz długie okresy realizacji dostaw i wysokie ceny zwłaszcza dla małej ilości realizowanych zakupów.

Powyższe uwarunkowania powodują to, że często efekt końcowy modernizacji jest znacznie uboższy od zamierzonego.

W zakończeniu należy stwierdzić, że modernizacja większości eksploatowanych elektrycznych zespołów trakcyjnych pozwoli na poprawe ich parametrów techniczno-eksploatacyjnych, komfortu podróżowania i poprawę warunków pracy obsługi znacznie szybszej i przy mniejszych nakładach niż zakup nowego taboru do realizacji przewozów w ruchu aglomeracyjnym i podmiejskim. W procesie wdrożenia do eksploatacji nowocześniejszego taboru należy dokonywać z jednej strony wymiany na tabor nowoczesny (przyszłościowy) z drugiej natomiast modernizować (jeżeli jest to opłacalne) tabor już eksploatowany. Te dwa kierunki powinny być realizowane równolegle.

Zaprezentowane przykłady modernizacji zespołów nie powinno zakończyć się na niewielkiej ich liczbie, a winny być kontynuowane zarówno na zamówienia głównego przewoźnika jaki jest PKP „Przewozy Regionalne", jak i na zamówienia spółek kolejowych (Kolei Regionalnych - Mazowieckich, Dolnośląskich, Wielkopolskich) powoływanych przez Urzędy Marszałkowskie, do których należy prawidłowe działanie przewozów w ruchu podmiejskim (aglomeracyjnym) i regionalnym. 


\section{LITERATURA}

[1] Biliński J., Marciniak Z: Modernizacje krajowych elektrycznych zespołów trakcyjnych do obstugi ruchu aglomeracyjnego i podmiejskiego. Materiaty konferencyjne XVIII Konferencji Naukowej Pojazdy Szynowe, Tom 2 str. 266277. Katowice - Ustroń, 2008 r.

[2] Kaska J., Pawlak Zdz., Sienicki A.: Modernizacja wózków typu $5 B / 6 B$ do elektrycznych zespołów trakcyjnych EN57 i EN71. Pojazdy Szynowe, $2003 \mathrm{nr} 4$.

[3] Marciniak Z.: Propozycje modernizacyjne elektrycznych zespołów trakcyjnych ze szczególnym uwzględnieniem taboru eksploatowanego $w$ lokomotywowni Kraków-Prokocin. Materialy Konferencyjne Kraków - Zembrzyce, 1996.

[4] Marciniak Z.: Propozycje modernizacyjne lokomotywy EP09 i elektrycznego zespolu trakcyjnego. Materiaty Konferencyjne ,Wybrane problemy transportu szynowego $w 150$ lecie kolei polskich" Kraków - Zakopane, 1997.
[5] Praca zbiorowa: Modernizacja elektrycznego zespotu trakcyjnego serii EW60 (6WEb). Tech-

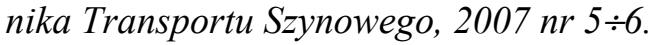

[6] Dokumentacja techniczno-ruchowa. Elektryczny zespót trakcyjny serii EW60 (6WEb). Praca ZNTK Mińsk Mazowiecki, 2007.

[7] Dokumentacja techniczno-ruchowa - Elektryczny zespót trakcyjny serii EN57: Praca ZNTK Mińsk Mazowiecki, 2005.

[8] Dokumentacja techniczno-ruchowa jednostki elektrycznej 5Bh+6Bh+5Bh. Opracowanie ZNTK Mińsk Mazowiecki, 2006.

[9] Dokumentacja techniczno-ruchowa - Elektryczny zespót trakcyjny EN57KM. Opracowanie ZNTK Mińsk Mazowiecki, 2007.

[10] Dokumentacja techniczno-ruchowa - Elektryczny zespót trakcyjny EN57SKM. Opracowanie ZNTK Mińsk Mazowiecki, 2007. 